\title{
Tenuous boundaries: women, domesticity and nationhood in 1930s Turkey
}

\section{Gülsüm Baydar}

Bilkent University, Ankara, Turkey

In the 1930s modern architecture was highly popularised in Turkey mostly through the widespread promotion of the modern house. In the early stages of nation building, the modern house became one of the most potent symbols of the modern nation, which aspired to enter the European economic, cultural and political milieu as an equal partner. The image of the modern Turkish woman played a somewhat similar role, her increasing access to various aspects of the public sphere being highly publicised as the success of Turkish modernisation. Despite obvious links between women and architecture, ranging from their active promotion as suitable images for the new nation to the physical appearance of women in public spaces, issues of gender and sexuality remained conspicuously absent from the architectural historiography of modern Turkey. In this paper, I offer critical readings of contemporaneous representations that relate the modern house and modern Turkish woman to uncover the complicated and contradictory levels that constitute the seemingly coherent narrative of architectural and cultural modernisation. The analysis of the relationship between sexuality, space and architectural discourse effectively complicates the architectural historiography of modern Turkey and shows the active participation of architecture in the production of the social/cultural realm.

\begin{abstract}
... [U]nobtrusively but crucially, a certain metaphor of woman has produced (rather than merely illustrated) a discourse that we are obliged 'historically' to call the discourse of man. ... [T]he discourse of man is in the metaphor of woman.
\end{abstract}

\section{Gayatri Chakravorty Spivak}

\section{Preamble}

The 1930s marked the most intensive period of modernisation in Turkey. The newly established Kemalist programme was determined to bring the young Republic into the European economic, cultural, and political milieu as an equal partner and advocated nationalistic idealism and progress through modernisation. ${ }^{2}$ Such reforms as changing the alphabet from Arabic script to Latin, adopting the Swiss Civil Code, and replacing the Ottoman fez with the European-style brimmed cap, signified important steps towards this goal. In the founding years of the Republic, visible symbols of modernity were actively deployed to publicise the image of the new nation state as a radical break from its Islamic Ottoman past. Within this context, both 'modern architecture' and 'the modern Turkish woman' constituted important components of the image repertoire of modern Turkey. 
Indeed, modern architecture fitted well into the search for a new architectural expression in the young Republic. The political/cultural demand to break with the Islamic Ottoman past, the active search for a contemporary lifestyle, invitation and employment of European architects and the need for fast and cheap construction are often cited as the reasons for its popularity. ${ }^{3}$ Modern architecture's main themes of rationalism and functionalism, its emphasis on health and efficiency, and promotion of new aesthetic sensibilities complemented the image of the modern, civilised and secular nation that Turkey aspired to become. As in the West, the modern house occupied the most significant portion of architectural discourse and practice in 1930s Turkey. Its aesthetic vocabulary of simplicity, functionality and rationality formed a desirable contrast to the heavily ornamented eclectism of late Ottoman architecture.

The image of the modern Turkish woman was promoted somewhat similarly. Her increasing access to various levels of education and appearance in the public sphere as a competent professional created a striking contrast to the image of the veiled Muslim woman relegated to the private domain of domestic interiors. In the political/ cultural domain, the recognition of women's suffrage (1934), their acquisition of legal rights to property and the abolition of polygamy (1926) marked significant breaks with the Islamic past. ${ }^{4}$ Women became highly visible agents of the modern project.

Despite obvious links between women and architecture, ranging from the physical appearance of women in public spaces to the active promotion of their new image, issues of gender and sexuality remained conspicuously absent from the architectural historiography of modern Turkey. In fact, only recent work has begun to reveal the complicated articulation between architectural form, political discourse, aesthetic conviction, ideological expression, cultural debates and nationalist sentiments. Within such a framework, Sibel Bozdogan demonstrates that the Republican discourse on women in Turkey had a prominent spatial and architectural component. ${ }^{5}$ In her work on Turkish architectural culture in the early Republic, Bozdogan explains how images of modern women were deployed to exemplify the success of the nation in detaching itself from the Ottoman past and how modern architecture was identified with the new Kemalist woman both symbolically and literally.

Most significantly, recent work in feminist studies has shown that the Kemalist woman is a complicated figure, which cannot be explained away solely by references to progressive aspects of modernisation in Turkey. ${ }^{6}$ Much is now written on how women were seen as agents of nationalist ideologies in the modernist project, rather than as autonomous subjects, who speak in their own right. Such work challenges the hitherto dominant notion that Republican reforms liberated women from the paternalistic order of the Islamic past. To abolish Islam did not automatically mean to abolish paternalism. Such criticism does not imply the wholesale denial of the significance of the Kemalist project however. On the contrary, it marks the continuation rather than rejection of the modernist project in Turkey. ${ }^{7}$ Adopting a similar perspective in architecture shows that the 
modern house played an active role not only in producing the pristine image of the modern nation but also the paternalistic mechanisms in its construction.

In what follows, rather than explaining the modern house in Turkey merely as a product and result of the developments in the political/cultural sphere, I will focus on the agency of architecture in the (re)production of the latter. Critical readings of contemporaneous representations that relate the modern house and modern Turkish woman uncover the complicated and contradictory levels that constitute the seemingly coherent narrative of architectural and cultural modernisation. ${ }^{8}$ In many ways, my examples are typical of their period. Yet they include inadvertent disclosures of the cracks and fissures in the coherence of the dominant fiction, in the manner of the Freudian slip of the tongue. $^{9}$ I capitalise on these slips, which reveal the irreducible role that the figure of the woman plays in the (de)construction of this fiction.

\section{Woman is the house}

As I was screening a large collection of articles from popular magazines of 1930s Turkey, two seemingly unrelated bedroom images stood out. The first one appears in an architectural context and illustrates the superior aesthetics of modern furniture. The second one belongs to an article on love and jealousy (Figs. 1 and 2). There is nothing unusual about these topics. Domesticity, marriage, family and women are familiar themes of such magazines and the 1930s marks the widespread promotion of modernist aesthetics in architecture and the visual arts. At first sight, these images can easily be

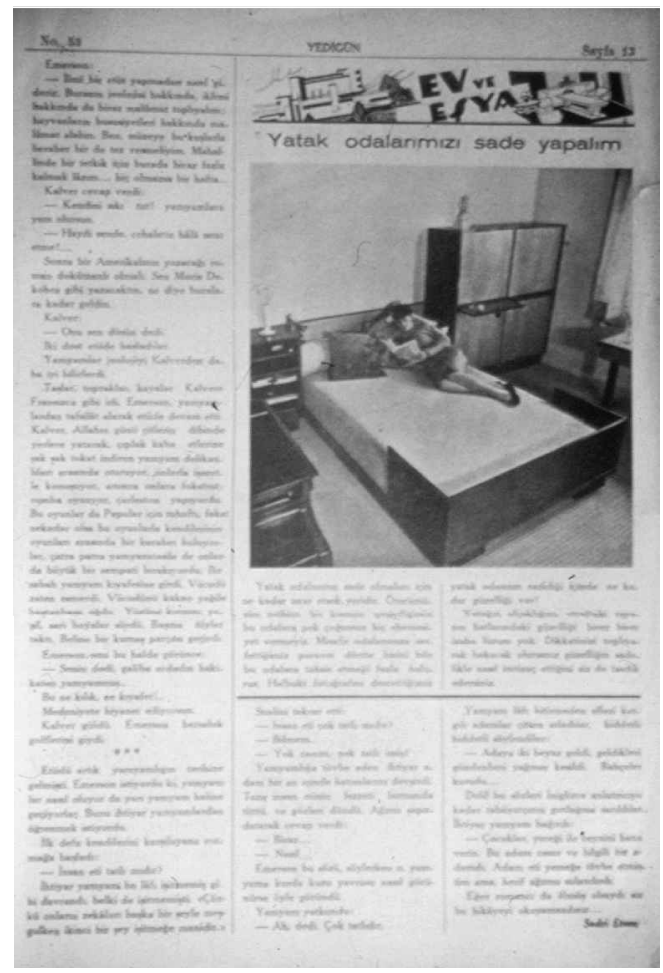

Figure 1. Illustration of a modern bedroom. 'Yatak Odalar, $m_{1} z_{1}$ Sade Yapal,m' (Let's make our bedrooms simple), Yedigün 53 (14 March 1934): p. 13. dismissed as innocent illustrations of what the texts explicate. However, upon closer inspection, they tell other stories which articulate with their historical context in intriguing and interesting ways.

The first illustration comes from the 'Home and Furniture' section of Yedigün (Seven Days), which used to feature modernist house plans, façades and domestic interiors on a weekly basis. ${ }^{10}$ The bedroom in question is a typical example. The caption reads: 
Figure 2. Illustration of an article on love and jealousy. 'Aşk ve

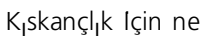
Söylemişler' (What has been said about love and jealousy), Resimli Ay 23 (January 1938): pp. 78-9.

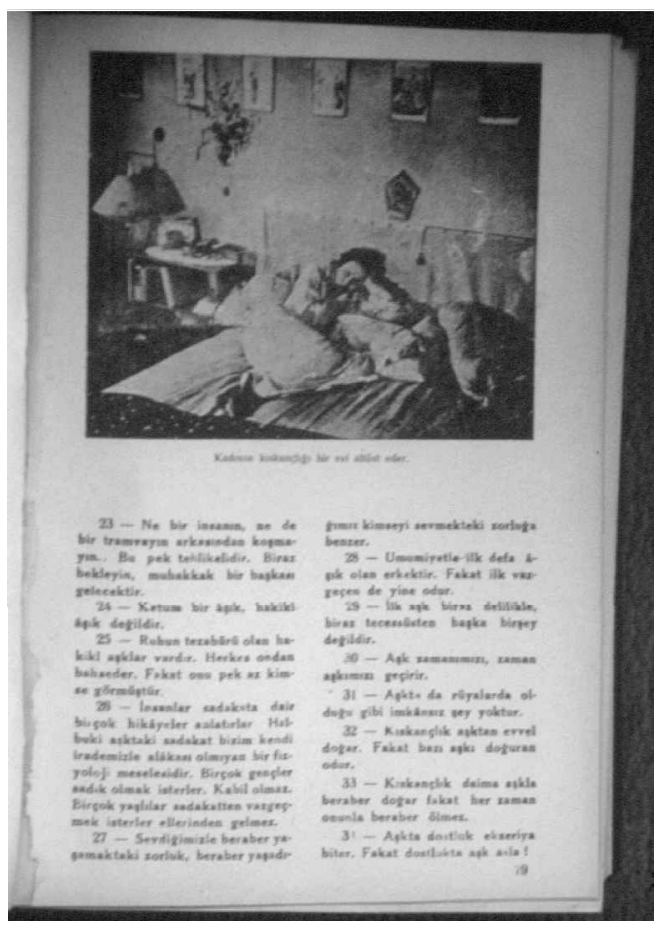

How beautiful is the bedroom in the photograph in its simplicity! The low-lying bed and the beauty of the contours of the furniture around do not call for explanation. If you look carefully, you will agree in the manner that beauty goes hand in hand with simplicity.

The photograph shows a bright and airy room with typically modernist furniture in sharp rectilinear outlines. If it were not for the figure of a seemingly relaxed woman reading a magazine lying on the bed, it bears the solemnity of an office space. The room is filled with sunlight, every object belongs to a proper place and the bed looks immaculate. What is striking in the caption is that the adjectives that are used to describe the interior, such as beauty in simplicity and beautiful contours, correspond to those that are used to describe the desirable attributes of the proper modern Turkish woman. In fact, the 'Home and Furniture' sections of Yedigün abound with similar phrases like 'simplicity and elegance', 'beauty without extravagance', and 'freedom from unnecessary adornment' to describe modern interiors. The figure of the proper woman seems to have worked as an appropriate metaphor for the modern house. ${ }^{11}$

The second bedroom, which appeared in Resimli Ay (Monthly Illustrated), illustrates a collection of aphorisms on love and jealousy.12 The photograph caption reads, 'woman's jealousy creates havoc in the house'. Like the first photograph, we have the partial view of a bedroom with a woman lying on the bed. The similarity ends there however. Further comparison involves a series of opposing qualities. In the first photograph every object is assigned a proper place. The walls are bare; the room is airy and spacious. Here we see pillows scattered on the bed, several pictures and a plant pot hanging on the wall with no apparent order, and a pile of small objects thrown on the bedside table. There is no trace of the containment, discipline and order that characterise the first room. Furthermore, unlike the equanimity of the woman in the first photograph, the woman here seems grounded in the bed with uncombed hair and an unsettlingly disturbed facial expression directed at the viewer. When I compare the two images from the point of view of women's 
representation in relation to space, the story gets more complicated. The second photograph is meant to illustrate a woman in a state of jealousy - a state which is intimately connected to her sexuality. When her sexuality is out of control, there remains no trace of domestic order.

From this perspective, the contained composure of the woman in the modern bedroom strikes me differently. She is a paradoxical figure, who seems both an inextricable component of the room that she occupies and a total alien at the same time. On one hand, her contained composure, unostentatious outfit and modern looks are in line with the architectural characteristics of the bedroom. In that sense she certainly belongs there, as a perfect illustration of the adjectives that are used to describe the room. On the other hand, being fully dressed with her shoes on, this woman seems to be placed on the bed temporarily, ready to leave after the flash of the camera. She is clearly not engaged in any function that a bedroom calls forth. One may argue that her figure is not even needed to make the point of the article. As opposed to the improper woman who inhabits the improper room in the second image, this one is the proper woman who dis-inhabits the proper bedroom.

These two scenes signal a complicated exchange between women and space, which is governed by notions of propriety and inhabitation. In fact, as feminist theorists have argued, the feminisation of space has a long history with serious ethical implications. Based on diverse examples from different historical and theoretical locations, Sue Best states that the association of space with the feminine, 'speaks of a persistent desire to domesticate space, to bring it within a human horizon and, most importantly, to "contain" it within this horizon'. ${ }^{13}$ How are notions of domestication and containment mobilised in the historical instant in question? Who decides the proper/improper boundary and on what basis? What is the relationship between the metaphor of woman in relation to the house and women's bodies that inhabit the modern house in the Turkish case?

\section{Man has the house}

The architecture of the modern house was widely promoted throughout the 1930 s by both the architectural and popular press. In 1931, Celal Esat, one of the most prolific architectural critics of the time, announced the arrival of 'New Architecture' to Turkey in an enthusiastic and jubilant tone. ${ }^{14}$ In his book bearing the same title, Celal Esat celebrates the principles of rationalism and functionalism and glorifies the formal opportunities that emerged by the use of new building technologies. In devoting a separate section to the 'new house', he emphasises its significance and suitability for modern life styles. Following a lengthy account of the architectural features of modern buildings, he adds:

Amongst all nations, Turkish architecture attracts particular attention for its rationality and affinity with modern architecture. That is why this new architecture will not look alien to us. ${ }^{15}$

At this point, Celal Esat's architectural focus is diffused by nationalist sentiments. Actually, domestic space was hardly confined to the realm of architectural interests in 1930s Turkey. Where almost every component of the cultural sphere was 
inscribed by ambitions to Westernise and modernise, the discourse on the modern house was intricately entangled with political and ideological interests. Architecture was a potent pedagogical site where modernist sentiments became highly visible. Architectural agency played an irreducible role in setting up the relationship between the individual citizen and the symbolic space of nationhood. In the euphoric decades of nation building, architectural and urban imagination flowed effortlessly between the notions of nation and building - building and nation building.

One of the most astounding narratives that links the modern house to the space of the nation appeared in Modern Türkiye Mecmuas, (Journal of Modern Turkey) in an article entitled, 'What is a house and how should a house be set up?'16 Stating that in Turkey 'the house is an institution and an organisation that now develops to be on par with the civilised level [of the Europeans]', the author introduces an astonishing history of the Turkish nation. According to him, the notion of settlement had been foreign to the Turkish people until the foundation of the Republic, since centuries of Ottoman conquests and defeats prevented the Turks from claiming any piece of land as their own. With the new national borders firmly established, however, the situation changed. The author explains:

The Turkish nation does not have its eyes set on other horizons. At the same time it does not even think of sacrificing an inch of the land that it rules. The Turkish nation has decided to settle permanently on this land, which it will rule forever. That is why iron and concrete bridges replace wooden ones, stone and concrete houses take the place of adobe constructions. Like many other good things, the Turkish citizen has just become familiar with the notion of home in the Republican period. ${ }^{17}$ This unusual narrative of the settlement process of the Turkish people enables the author to move between national and architectural boundaries with alarming ease. As the article continues, the idea is that the modern house is home for the Turkish subject in the same way as national borders mean home for Turkish citizenry. Inhabiting the house and inhabiting the nation are conceived as one. The modern house seems to bear a much bigger burden than its material propriety in terms of conforming to modernist architectural principles. It is the material embodiment of the imaginary link between the spheres of the nation and the individual. In this account, its owner is primarily identified with the figure of the 'Turkish citizen'. Furthermore, this figure is unmistakably sexed as male. Throughout the article, there are a number of references to the house that confirm this point. The author describes it as 'a place to rest when one comes back from work at night', and refers to the 'owner's study room' and 'study table'. The woman in the house, on the other hand, is explicitly referred as the 'house-wife', with no apparent relation to the realm of the workplace. In fact man's ownership of the house was already institutionalised by the 1926 Civil Code, which states that the husband is not only the head of the family and the representative of the marriage union, but also holds the privilege of choosing the place of residence for the family. ${ }^{18}$ 
How then does this masculine figure occupy the house? In 'What is a house and how should a house be set up?' another figure, identified as 'the European', sets the standards. The author says, 'when a European couple sets out to build a house, the first thing they think about is their comfort'. Later on he continues to explain, 'for the European, the house is something private, belonging to the individual' (emphases mine). ${ }^{19}$ Throughout the article, the figure of the anonymous European haunts every notion of the modern house. S/he seems to be an idealised subject without a particular nationality, class and gender, who inhabits the ideal modern house. The author goes on to explain that a person who furnishes a modern house 'can be proud of it and show it to a foreigner without any embarrassment'. What strikes me here is the introduction of the figure of the foreigner. Those who are invited to see one's house, are commonly called guests rather than foreigners. The former term resonates with a tone of intimacy and familiarity that is hardly associated with the figure of a foreigner. ${ }^{20}$ Furthermore, in the Turkish language, the term foreigner denotes a foreign national as well as an unfamiliar person. Hence the two figures, the European and the foreigner, who are introduced as the outsiders to the modern Turkish house, can be easily juxtaposed.

The architecture of the modern house with its large glass surfaces is intricately intertwined with this scenario of exhibitionism and voyeurism. Three photographs in 'What is a house and how should a house be set up?' clarify this point. The first one, captioned, 'a beautiful bird cage in a modern house', shows an undecorated but fully equipped and very ordinary birdcage hanging inside the circular frame of a tubular metal stand, complete with a bird (Fig. 3). Initially I was amused to see this trivial object right next to the bold fonts of the article's title. Although references to undecorated and functional furniture such as living or dining room sets, cupboards and beds are abundant in the discourse on the modern Turkish house, a birdcage should hardly be an object worthy of architectural deliberation. Considered in relation to the

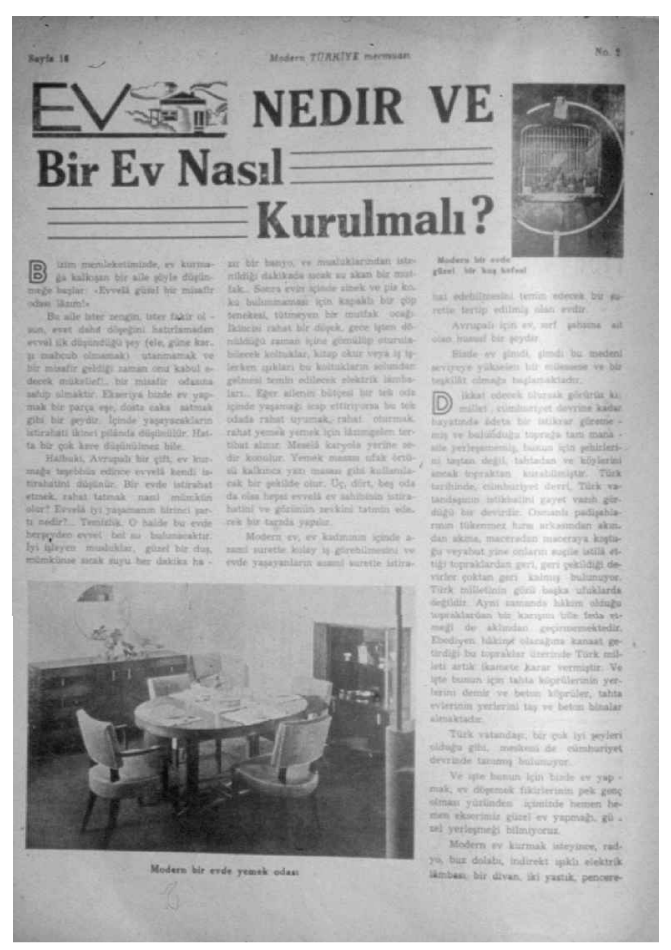

Figure 3. Illustration of a bird cage in an article on the modern house. 'Ev Nedir ve Bir Ev Nasl Kurulmal,?' [What is a house and how should a house be set up?], Modern Türkiye Mecmuas 1,2 (1938): p. 16. 
Figure 4. Interior and façade of a modern house. 'Ev Nedir ve Bir Ev Nas,l

Kurulmal,?' [What is a house and how should a house be set up?], Modern Türkiye Mecmuası, 2 (1938): p. 17.

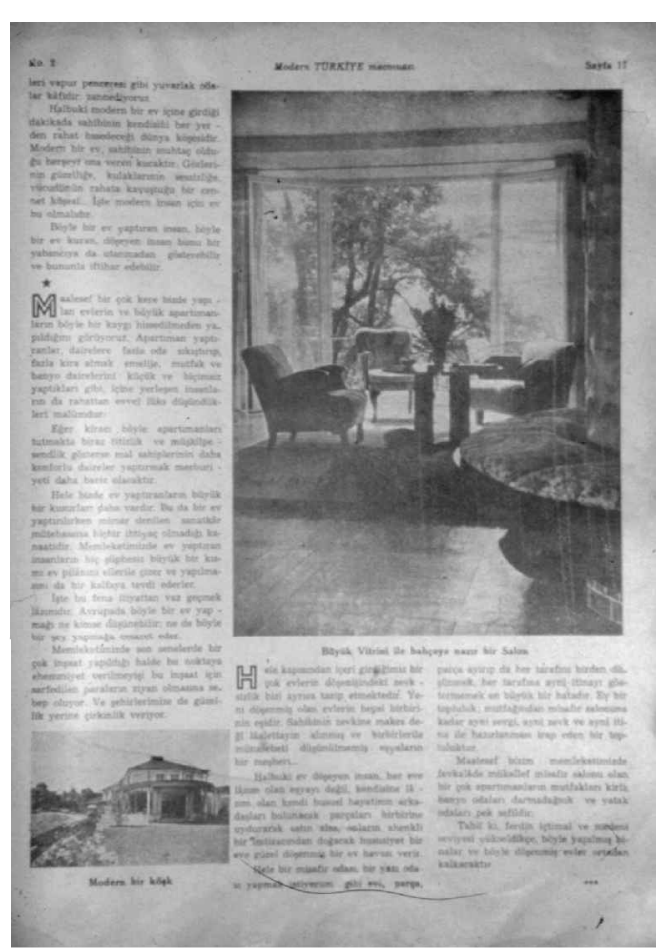

second illustration, however, it takes on a significant meaning. This is a photograph of a curvilinear façade rendered transparent by the use of large windows with thin frames (Fig. 4, bottom). It looked like quite an ordinary modern façade to me until I connected the two images. Indeed, the façade seemed to replicate the birdcage in gigantic proportions. The third photograph, an interior view, further accentuates this similarity (Fig. 4, top). The caption reads: 'A hall that has a view to the

garden through its large display-window.' In its common use, the term display-window hardly applies to the architecture of the house, as it structures the gaze from the outside in. In this case its use makes total sense, however, in view of the statement that the interior is offered to the gaze of the foreigner. The architecture of the house structures the relationship between the foreign spectator and the occupant. Here, the transparent façade produces the modern Turkish citizen and the foreigner similarly to the birdcage, which produces the bird as an object and its viewer as the gaze.

Following this logic, as the metaphor of national borders and under the imaginary gaze of the foreigner, the tenuous boundaries of the modern Turkish house need to be under permanent control. However, this unhomely image is effectively and conveniently dispelled when the author states:

A modern house is an open arm that answers every need of its owner. It is a heavenly corner where his eyes meet beauty, his ears receive quietude, and his body receives comfort. ${ }^{21}$

The feminised discourse of the modern interior that I mentioned earlier is further accentuated here. The modern house not only is simple, beautiful and unostentatious, but also offers quietude, comfort and care. It is doubly feminised, both by analogy to the woman's desirable appearance and to her naturalised maternal capacity to love and nurture. In order for man to have the house, woman has to be the house. In other words, she needs to be the site of support for man's ownership and control. ${ }^{22}$ It seems like the modern Turkish house has no room for the woman as a speaking subject. 
Then what kind of inclusions and exclusions operate to cover up this repression in a newly founded modern nation where women's rights occupy a considerable portion of the cultural/political agenda? What kind of feminine identification is constructed in relation to the house? Who is the modern woman who inhabits the modern house in modern Turkey? To answer these questions it is necessary to turn from the feminised metaphor of the house to the body of the woman in the house.

\section{Woman in the house}

Women's increasing access to the public realm in education, professional employment and entertainment featured prominently in the popular press of the 1930s. Many of Kemal Atatürk's speeches and numerous contemporaneous publications actively promoted the image of the modern Turkish woman. At first sight, the celebration of her public image as an educated professional and her simultaneous identification with the nurturing image of domesticity seem paradoxical. ${ }^{23}$ However, this paradox is powerfully covered under the masculinist discourse of nationalism.

One of Atatürk's passionate speeches of 1925 is a paradigmatic example of the underlying tone of this discourse. Addressing a mixed crowd of men and women, the founder of the Republic says:

Friends ... our women, like us are intelligent and thoughtful people. Once we inject them with consecrated morality, explain them our national moral values and adorn their brains with enlightenment and purity, there is no need for selfishness. Let them show their faces to the world. And let them see the world with the careful attention of their own eyes. There is nothing to fear in this. ${ }^{24}$ (Emphases mine.) If fear seems a strange notion to introduce at this junction, it is perhaps the most appropriate one to highlight the fissures in the theoretical premises that link domesticity, women and nationhood. As feminist theorists have argued, the feminine figure plays a double-sided role in masculinist discourses. On one hand, she represents a docile and familiar entity to be dominated. On the other hand, she is the signifier of precarious boundaries and hence the source of anxiety and fear. ${ }^{25}$ Atatürk's speech is an astoundingly clear demonstration of the role of the feminine figure in the masculinist discourse of nationalism. Furthermore, the us versus them mentality in his speech leaves no doubt about the gender hierarchies that are preserved in the new discourse on women's rights. The potentially unruly woman is allowed to have a public face only after being re-formed by men. She needs to be tamed by men's national and moral values in order not pose any threat. Her relationship to these values is explained in another speech by Atatürk:

What should a Turkish woman be like? The Turkish woman should be the most enlightened the most virtuous and the most dignified woman in the world.... The duty of the Turkish woman is to raise future generations with the necessary vigour to protect and defend the Turkish nation with intelligence, wisdom, strength and determination. ${ }^{26}$

This is not an isolated instance whereby maternal qualities of women take centre stage for the higher good of the nation. Such accounts reinforce the dominant nationalist discourse, which is based on 
masculine attributes of domination and control. The fantasy of woman as enlightened mother sustains the scenario of the coherent modern nation. This point is made explicit by the popular press as well. In one of the most telling instances in 1937, the editorial of the inaugural issue of Ev-lş (Home-Work), states that the house provides the support for the Republican revolution and Turkish society. ${ }^{27}$

The metaphorical exchange that is established between the nation, the modern house and the Turkish woman is materialised in actual political and cultural practices. Notions of boundary and control re-enter the scenario in relation to women's bodies. The latter is an obsessive theme of the popular journals of the 1930s, prominently featured not only in fashion and beauty sections but also in articles on sports, health and social life. Detailed explanations of the importance of sports and exercise almost exclusively illustrate only women's bodies. They emphasise precision and perfection in the movements and the measurements of the body. An article on a girl's youth camp describes young women in bathing suits as 'healthy, tanned, robust girls, each looking like a statue of health'. ${ }^{28}$ Articles on adolescent health describe proper measures in dealing with high-school girls' bodily and emotional disorders. ${ }^{29}$ These magazines enthusiastically publicise the trade schools that are established in major cities to educate women on proper 'scientific' conduct of housework, sewing and gardening. Such institutions produce the efficient women of the efficient modern house. Remarkably, the authors of almost all these articles are men. As one contemporary theorist put it, 'men gave social birth to the new woman of the Republic.' ${ }^{30}$ Women's bodies are sites of discipline, control and regulation. Their contours need to be carefully delineated to overcome lack and to guard against excess.

This point is clearly explicated in 1938, by the renowned author and journalist Peyami Safa who offers a concise summary of the idealised woman in the dominant fiction of modern Turkey by identifying four types. ${ }^{31}$ The first type, according to him, is the aggressive, intolerably independent and vocal feminist-socialist woman with unmistakably masculine attributes. She is neither modern, nor Turkish, nor woman. The second type is the spoilt, degenerate bourgeois, who consumes her time in beauty parlours, shops, ballrooms and exhibition halls. The gossipy housewife is the third type. With no interest outside the narrow circuit of her neighbourhood events, she is unimaginative, ignorant and boring. These figures bear the mark of lack (of knowledge, national qualities and womanhood) or excess (of independence, language, publicity). The last type is the real modern Turkish woman. The author explains:

As it applies to all women from time immemorial to eternity, the headquarters of the modern Turkish woman is her house. But all the virtues, attractions and excitement of nature and society will flow inside this house by means of fresh air, sunlight, books, radio, etc. ... The modern Turkish woman differs from her predecessors ... by being an enlightened woman and mother who carries out her domestic and parental duties with love, knowledge and technical skills, besides having some understanding of world events. 
So long as she sticks to this principle, every step that she takes, even if it leads to masculine tasks, will be beneficial to her. So long as she sticks to this principle, her love for toiletry and sports will improve her health and beauty. ${ }^{32}$

This is a remarkable statement that conjoins the nation, the architecture of the modern house and woman in one breath. Fresh air and sunlight, the essential qualities of the modern house bring the outside world in. However, it turns out that this is only to enlighten the woman in the house so that she can conduct her domestic and maternal duties with knowledge and precision.

All of these examples illustrate that the modern Turkish woman was formed by her subjection to the nationalist symbolic realm of domination and control. Not surprisingly then, she is only heard when she speaks the language which 'others' herself, i.e. the masculinist language of nationalism. This is not to overlook the fact that in some cases, the latter worked efficiently to benefit women's participation in the public realm. For example, the activities of the most prominent women's organisation, Turkish Women's Association (Türk Kad,nlar Birligi) was instrumental in the recognition of women's suffrage. ${ }^{33}$ On the other hand, when numerous journal articles of the 1930s featured individual women who worked outside their homes in various trades and professions, their emphasis remained almost exclusively on these women's altruism. They are proudly portrayed either as sacrificing family life for the good of the nation or selflessly generating income to support their families. Typical examples include a newly appointed member of the parliament who is quoted as saying that she does not live for herself but for her nation, and a young fruit-seller who takes care of her mother, who is introduced as 'a real lady; a conscientious Turkish woman who earns her life under demanding conditions'. ${ }^{34}$ The working woman presents an acceptable image to the extent that she is self-less.

The glorification of domestic life, on the other hand, is strikingly highlighted by the title of one article, 'Let professional life be yours, I am contented with my new house', which is authored by a woman who resigned from her job to dedicate herself to her house, family and children. ${ }^{35}$ Women's responsibilities at home were further emphasised by the programmes of women's organisations, which were mostly confined to educating them in areas pertaining to domestic work. Interestingly, in 1935 a newly appointed woman representative in the parliament declared that she did not intend to represent women's issues. According to her, as Turkish women had obtained all the rights that had been previously denied to them, there was no need for women's organisations anymore. ${ }^{36}$ The complicated and often unsettling aspects of the relationship between the new woman, the public sphere and the domestic realm were powerfully hidden by the success of the administrative and legal reforms, which enabled women's unprecedented appearance in areas previously confined to men. Discourses on the modern Turkish woman and the architecture of the modern house silently participated in the production of the masculinist practices of the young Republic. 


\section{Conclusion}

In 1930s Turkey, nationalist and modernist discourses intricately articulated with the representation of women in relation to space. The public space of nationhood, the privacy of the house and the feminine figure intertwined in complicated ways. Metaphors abound. The boundaries of women's bodies and the feminine sphere, architectural boundaries and national borders are superimposed. Boundaries are sites of encounter between the self and the other. As such, they are sites of potential threat to be controlled and guarded against invasion. In the architectural and cultural instances that I focused, the feminine figure always appears as the metaphor for the disorderly element that threatens the dominant fiction, which produces the nation. As Geraldine Heng and Janadas Devan have argued in another context, 'women, and all signs of the feminine, are by definition always and already anti-national. ${ }^{37}$

In the early years of the Republic, discourses on the modern house and the modern Turkish woman are juxtaposed at a number of levels to aid the production of the masculine realm of nationhood. First of all, the modern house is seen as the microcosm of the space of the nation. As such, it is owned and guarded by man. It is the metaphor of a space that men protect against foreigners. At this level, the woman in the house literally nurtures the heroic masculine figure, which is associated with the nation. Secondly, the metaphoric identification of woman with the house reveals the masculine desire of regulation and control. Both the modern house and the modern Turkish woman are desired to be highly visible with similar characteristics of beauty and elegance without extravagance. Woman is effectively stripped of her sexualised agency, which is always already in excess of the nationalist agenda of modern Turkey.

The boundaries of the modern house, which are rendered analogous to national borders, need to regulate feminine sexuality and display the figure of the proper woman to the modernist gaze. The modern house, like the birdcage, traps and domesticates the feminine element and puts her on display. Architectural representations of the modern house in Turkey implicitly participate in the production of the modern Turkish woman. The discordant image of the fully dressed modern woman lying on the modern bed, with which I began this article, is a striking illustration of the repression that is involved in the production of the proper Turkish woman by the nationalist discourse of modernism. The masculinist discourse, which produced nationalism, simultaneously produced the modern house as the proper place of the modern Turkish woman. Yet the image in question is a subtle reminder that she is perhaps not quite at home in her proper place.

Recent feminist work on early Republican Turkey, which reveals women's complicated relationship to nationhood, also enables fresh perspectives to understand the relationship between sexuality, space and architectural discourse. Women's bodies and the architecture of the house are mutually inscribed in the production of the space of the nation. The analysis of the architectural mechanisms that produced and reinforced the proper image of the modern Turkish woman both effectively complicates the architectural historiography 
of Modern Turkey and shows the active participation of architecture in the production of the social/ cultural realm. In terms of the relation between women and space, the Kemalist project of modernity consists of complicated and contradictory levels, the unpacking of which enables critical positions beyond its sanctified acceptance and wholesale denial.

\section{Notes and references}

I would like to thank Hilde Heynen and Lieven De Cauter for their helpful and valuable comments in the development of this paper. They helped me to understand and contextualise my architectural interpretations in both social/historical and also intimately personal terms as a granddaughter of the Kemalist revolution.

1. Gayatri Chakravorty Spivak, 'Displacement and the discourse of woman' in Displacement: Derrida and After (Bloomingron, Indiana University Press, 1983), p. 169.

2. The term Kemalist refers to Kemal Atatürk, the founder of the Turkish Republic in 1923.

3. For an extensive explanation see, Afife Batur, 'To be modern: search for a republican architecture' in Renata Holod and Ahmet Evin (eds.), Modern Turkish Architecture (Philadelphia, University of Pennsylvania Press, 1984), pp. 68-93.

4. For a critical account of the period see, Yeşim Arat, 'The project of modernity and women in Turkey' in Sibel Bozdogan and Reşat Kasaba (eds.), Rethinking Modernity and National Identity in Turkey (Seattle, University of Washington Press, 1997), pp. 95-112.

5. Sibel Bozdogan, Modernism and Nation Building: Turkish Architectural Culture in the Early Republic (Seattle, University of Washington Press, 2001).
6. While Bozdogan too acknowledges this point, her emphasis remains on the progressive aspects of the reforms.

7. Yeşim Arat states that, 'the emergence of feminism attests to the vigor of the modernist project. The project continues as it is liberated from the monopoly of Kemalist discourse and regenerated by a plurality of voices, including feminisms critical of Kemalist modernism.' Yeşim Arat, 'The project of modernity and women in Turkey' in Sibel Bozdogan and Reşat Kasaba (eds.), Rethinking Modernity and National Identity in Turkey (Seattle, University of Washington Press, 1997), p. 96.

8. In what follows I focus solely on urban architecture. The promotion of modern architecture in rural areas in relation to the status of rural women is a significant topic yet to be researched. However, the Republican reforms remained a remote ideal for the vast majority of rural women. See, Deniz Kandiyoti, 'Gendering the modern' in Bozdogan and Kasaba, Rethinking Modernity, op. cit., p. 125.

9. I borrow the term 'dominant fiction' from Kaja Silverman, which is what passes for reality in a given society. See Kaja Silverman, The Threshold of the Visible World (London, Routledge, 1996), p. 178.

10. 'Yatak Odalar, $m_{1} z_{1}$ Sade Yapal,m' (Let's make our bedrooms simple), Yedigün 53 (14 March 1934): 13 Yedigün was a richly illustrated weekly journal, which included a broad range of articles including politics, sports, childrearing, literature, fashion and architecture. Like other popular journals that I cite below, its aim was to educate the public along Republican ideals.

11. The correspondence of terms that describe modern architecture and modern woman is also mentioned in Bozdogan, Modernism and Nation Building, op. cit., p. 80. 
12. "Aşk ve $K_{1}$ skançlık Için ne Söylemişler" (What has been said about love and jealousy), Resimli Ay 23 (January 1938): pp. 78-9. In terms of its editorial intentions Resimli Ay was similar to Yedigün. It was a monthly publication, with particular focus on literary topics.

13. Sue Best, 'Sexualizing space' in Elizabeth Grosz and Elspeth Probyn, (eds.), Sexy Bodies (London, Routledge, 1995), p. 183.

14. Celal Esat, Yeni Mimar (Istanbul, Agah Sabri Kitaphanesi, 1931).

15. Ibid., pp. 8-9.

16. 'Ev Nedir ve Bir Ev Nas, I Kurulmal,?' [What is a house and how should a house be set up?], Modern Türkiye Mecmuas , 2 (1938): pp. 16-17. Although the article bears no signature, both its tone and vocabulary strongly suggest that it is written by an architect. Since the majority of the architects and almost all of those who wrote on architecture at that time were male, I will use 'he' to refer to the author. Although the journal often featured architectural topics, it included a broad range of articles on almost all aspects of everyday life in Republican Turkey.

17. Ibid., p. 16.

18. Yeşim Arat, 'The project of modernity and women in Turkey' op. cit., p. 105.

19. Ibid., p. 16.

20. Furthermore, 'the guestroom' has a long tradition in middle and upper middle class houses in Turkey. It is the room that contains the most valuable furnishings and is only used upon the arrival of guests. In fact 'What is a house and how should a house be set up?' begins by criticising that Turkish families think of the guestroom before their own comfort when they set up a house, as their priority is 'to show off to friends and acquaintances.' As Turkish architectural discourse and practice of the 1930s indicate, there had been a considerable change in the architecture of the modern house in relation to the guest. Emphasising that modern living had externalised many activities, such as large gatherings and work-related meetings that previously took place at home, one architect stated that 'the guest room is an unnecessary luxury for our present needs'. (Abdullah Ziya, 'Binan,n Içinde Mimar' (The Architect in the Building), Mimar 1 (1931): p. 15.

21. Ibid., p. 17.

22. This interpretation draws from the psychoanalytic account of man 'having' versus woman 'being' the phallus. For an extensive explanation, see Judith Butler, Gender Trouble (New York, Routledge, 1990), pp. 43-47.

23. Sibel Bozdogan draws attention to this paradox in Modernism and Nation Building, op. cit., p. 197. Here I am interested in the mechanisms that suppress it.

24. Speech given in Inebolu on 28 August 1925, published in M. Rauf Inan, Atatürk ve Türk Kad,n, (Atatürk and the Turkish Woman) (Istanbul, Ark,n Kitabevi, 1991), p. 52.

25. This point is elaborated in Sue Best, 'Sexualizing space' op. cit., p. 183.

26. Speech given on 14 October 1925, at Women's School of Education in Izmir. Atatürk ve Türk Kadin, op. cit., pp. 54-5.

27. Quoted in Ayşe Durakbaşa, 'Cumhuriyet Döneminde Modern Kad,n ve Erkek Kimliklerinin Oluşumu: Kemalist Kad,n Kimligi ve "Münewer Erkekler"' [The formation of identities of modern women and men in the Republican period: the identity of the Kemalist woman and 'enlightened men'] in Ayşe B. Hac,mirzaoglu, (ed.), 75 Y,lda Kad,nlar ve Erkekler [Women and Men in 75 Years] (Istanbul, Tarih Vakf, 1998), p. 46. For the emphasis on the maternal qualities of modern Turkish women in the nationalist discourse also see: Yeşim Arat, 'The project of modernity and women in Turkey' and Deniz 
Kandiyoti, 'Gendering the modern' op. cit., pp. 95-112, 113-132.

28. Hikmet Feridun, 'Erkeklere Yasak Olan Bir Yer: Genç K zlar Kamp' (A forbidden place for men: youth camp for girls) Yedigün 6/131 (11 September 1935): pp. 14-15.

29. 'Liseli $K_{1} z l a r_{1} m_{1} z_{1} n S_{1}$ hhati' (The health of our highschool girls), Muhit, 4/38 (December 1931): pp. 52-3. The anonymous author states that he summarises the views of a doctor published in Good Housekeeping. 'Genç K/zlar,m,za Takayyütler' (Precautionary measures for our young girls), Muhit, 3/31 (May 1931): pp. 44-5.

30. Deniz Kandiyoti, 'Gendering the Modern' in Bozdogan and Kasaba, Rethinking Modernity, op. cit., p. 123. Ayşe Durakbaşa draws attention to the fact that 'women's issues' had been predominantly addressed by men since the Westernisation period in the Ottoman Empire in the early nineteenth century. See, 'Cumhuriyet Döneminde Modern Kad,n ve Erkek Kimliklerinin Oluşumu: Kemalist Kad,n Kimligi ve "Münevver Erkekler"' [The formation of identities of modern women and men in the Republican period: The identity of the Kemalist woman and 'enlightened men'] in Ayşe B. Hacımirzaoglu, (ed.), 75 Yllda Kad,nlar ve Erkekler [Women and Men in 75 Years] op. cit., p. 37.

31. Peyami Safa, 'Modern Türk $\mathrm{K}_{1} \mathrm{Z}_{1}, '$ Modern Türkiye Mecmuas, 1/1 (March 1938): p. 4; 1/2 (March 1938): p. $5 ; 1 / 4$ (March 1938): p. 5; $1 / 6$ (April 1938): p. 9.

32. Ibid., 1/6 (April 1938): p. 9. In 1937, Peyami Safa had a debate with another intellectual, Ismail Hakk, Baltac oglu. The latter was of the opinion that all housework and childcare could be overtaken by machines and social institutions. Interestingly, while promoting the professional modern woman, Baltac,oglu still argued that, 'the new woman is one with a positive mind to educate her children and to deserve lifelong companionship of men'. See, Duygu Köksal, '1930'lar ve 40'larda Kad,n, Cinsiyet ve Ulus' [Woman, Sexuality and Nationhood in the 1930s and 40s], Toplumsal Tarih 51 (March 1998), pp. 31-5.

33. When the Peoples Party of Women (Kadınlar Halk $F_{1} r k a s_{l}$ ) was not recognised by the government because of the political implications of the term party, it was re-founded under the name Turkish Women's Association (Türk Kad,nlar Birligi). Interestingly, the former insisted on its non-political aims, stating that the primary duties of women consisted of motherhood, and family affairs. (Zafer Toprak, 'Kad,nlar Halk F,rkas,' (Women's People Party), Tarih ve Toplum 9/51 (March 1988): p. 158). Both the Party and the Association placed primary emphasis on educating women along the lines of Republican ideals of civilisation and progress. Ironically, the Association actively promoted women's political agency besides organising a variety of skills-related courses ranging from driving to sewing. (Leyla Kaplan, Cemiyetlerde ve Siyasi Teşk,latlarda Türk Kad,ni: 1908-1960 [Turkish Women in Societies and Political Organisations] (Ankara, Ataürk Kültür, Dil ve Tarih Yüksek Kurumu, 1998), p. 141). Women got the right to political representation in municipal governments in 1930 and in the parliament in 1934.

34. Musa, 'Saylav Fakihe Bursa Muhabirimize Hayat, $n_{1}$ Anlat,yor' [Member of Parliament Fakihe tells her life story to our Bursa correspondant], Yedigün, 4/104 (6 March 1935): p. 13; Mekki Sait, 'Zarzavatçı Fatma Han,m' [Fruit-seller Ms. Fatma], Yedigün, 3/44 (10 January 1934): p. 11. Fatmagül Berktay points out that the proper women of the early Republic were portrayed either as de-sexualised public figures or as mothers of the family and the nation. 'Cumhuriyetin $75 Y_{1} l_{1} k$ Serüvenine Kad,nlar Aç, $S_{l}$ ndan Bakmak', [Looking at the 75 year adventures of the Republic 
Tenuous boundaries women, domesticity and nationhood in 1930s Turkey Gülsüm Baydar

from women's perspective] in Hac,mirzaoglu, (ed.), 75 Y,lda Kad,nlar ve Erkekler, op. cit., p. 3.

35. Müfide Muzaffer, 'Memuriyet Sizin Olsun!. Yeni Kavuştugum Evim Bana Yeter,' Muhit, 4/46 (1932), pp. 36-7. Also cited in Bozdogan, 'Living modern' op. cit., p. 317. I thank Sibel Bozdogan for making this article available to me.
36. 'Saylav Türkan' Yedigün, 4/103 (27 February 1935): p. 15.

37. Geraldine Heng and Janadas Devan, 'State fatherhood: the politics of nationalism, sexuality, and race in Singapore' in Nationalisms and Sexualities, Andrew Parker, Mary Russo et al. (eds.), (New York, Routledge, 1991), p. 356. 